\title{
Enriching perspectives: experienced ecosystem services in rural Mozambique and the importance of a gendered livelihood approach to resist reductionist analyses of local culture
}

\author{
$\underline{\text { Juliana Porsani }}^{1}$, Lowe Börjeson $^{2}$, Rickard Lalander $^{1}$, Kari Lehtilä $^{1}$ and Angelina R. O. Martins ${ }^{3}$
}

\begin{abstract}
Based on a case study from rural Mozambique, we stress that ecosystem services research may be enriched through gendered livelihood approaches, particularly in terms of experienced ecosystem services. Ecosystem services studies have been accused of being gender blind. We argue for the value of open narratives that are attentive to the gender dynamics underpinning the production and reproduction of livelihoods. By focusing on the experienced gender dimension of ecosystem services, livelihood perspectives fulfill the normative role of providing a people-centered means to assess the values of the environment "from below" and can therefore constitute an entry point to a holistic understanding of by whom, how, when, and why the environment is experienced as valuable. Our findings stress the dynamism and plurality of experienced ecosystem services (i.e., they vary across groups and time and cross-cut material and immaterial dimensions), as well as the asymmetrical gendered and fundamentally cultural relations that they enable. Accounting for the experienced gender dimension of ecosystem services is critical to contextualize the environment in people's lifeworlds and to make understandings of ecosystem services representative of, and instrumental to, people's voices and agendas. We show how such enriched, diverse, bottom-up ecosystem services perspectives form an essential foundation (together with ecological research) for resisting applications of reductionist top-down categories assumed to represent general local values.
\end{abstract}

Key Words: cultural embeddedness; experienced ecosystem services; gender; livelihoods; Mozambique; Nguava

\section{INTRODUCTION}

How may a gendered livelihood approach to people's everyday experiences in rural settings benefit research on ecosystem services? Our aim here is twofold. First, we provide a case study of gendered livelihood conditions in Nguava, Mozambique. Second, and equally important to and intertwined with the first aim, our theoretical-methodological argument claims that ecosystem services research may be enriched through insights from gendered livelihood perspectives, particularly in terms of experienced ecosystem services. What our results mainly show is that such an approach may help to accomplish the following objectives:

1. To articulate how gender-based productive and reproductive labor processes are shaped by differentiated socialecological relations, which tend to be disregarded in assessments that do not contextualize the experienced importance of the environment in people's lifeworld;

2. To show how gendered livelihood practices intersect with other kinds of social statuses and yield multiple and varying experienced values of the environment (e.g., the sustenance of spiritual and ceremonial practices, the nurturing of social ties and of senses of place and home, the exercise of belief and knowledge systems, the exercise or challenging of social roles and norms, and access to productive assets);

3. To understand the basis for differentiated responses by people facing diverse constraints and opportunities in times of difficulty and crisis; and

4. To expand the conceptual and methodological inclusiveness of the field, strengthening ecosystem services research as an instrument that is able to capture and represent diverse local views and values that transcend the materiality of natural resource flows and services.

Livelihoods contribute to shaping the environment, affecting its capacity to provide ecosystem services. In turn, ecosystem services are central for livelihoods because they are fundamental for life and contribute to determining people's everyday experiences. Nonetheless, although it is often acknowledged in ecosystem services studies that "within each community, different groups have different interests, livelihood strategies, demographics, networks, and interactions with ecosystems" (Folke et al. 2005, Daw et al. 2011), oftentimes, "local people" or "communities" are the objects of coarse analysis that tends to homogenize humans in specific locations (Daw et al. 2011, 2015). This tendency is clear in studies that approach individuals in a location as a common group of stakeholders who are in contrast to external stakeholders (e.g., rural vs. urban inhabitants or community inhabitants vs. outsider investors and tourists; e.g., Maass et al. 2005, Agbenyega et al. 2009, Nahuelhual et al. 2016). Accordingly, this tendency has resulted in a gender "blind spot" in ecosystem services research (Cruz-Garcia et al. 2017, Yang et al. 2018). Even in participatory assessments that seek to reveal views and opinions, gendered standpoints are often reported in a conflated form that purports to represent a single community view (Paudyal et al. 2015, Reilly et al. 2018). This gender blindness limits the understanding of how gender intersects with ecosystem services, an area of study that is particularly important in developing countries, where the rural poor rely considerably on the nearby environment (World Resources Institute et al. 2005, Brown and Fortnam 2018).

When gender differences are addressed in relation to ecosystem services, researchers tend to use categories or elements that have

${ }^{1}$ School of Natural Sciences, Technology and Environmental Studies, Södertörn University, Sweden, ${ }^{2}$ Department of Human Geography, Stockholm University, Sweden, ${ }^{3}$ Department of Biological Sciences, Eduardo Mondlane University, Mozambique 
been assumed a priori to embed local value (e.g., different categories of ecosystem services or different elements in the environment; Hamann et al. 2016). This partial incorporation of local perspectives is problematic because it limits a scientific, holistic understanding of how people experience the environment; such experiences are fundamentally varied in areas where gendered social relations strongly mediate the access, use, and benefits that different social groups derive from the environment.

Accordingly, we performed a gendered livelihood analysis to unpack the "locals" in a specific setting and assess how, why, and by whom the environment is experienced as valuable based on people's diverse everyday experiences. The analysis of gender and livelihood relations highlights that experienced ecosystem services are embedded in context. Distinguishing diverse local views is crucial in designing effective environmental management plans and policies that are locally and culturally contextualized. Our results can thus contribute to addressing some important challenges faced by ecosystem services studies by expanding the conceptual and methodological inclusiveness of the field and strengthening ecosystem services research as an instrument that is able to capture and represent diverse local views (Raymond et al. 2013, Barnaud and Antona 2014, Jackson and Palmer 2015, Díaz et al. 2018, Peterson et al. 2018). Inclusiveness and representativeness are particularly critical in places marked by "the extraction of natural resources, in large volume and intensity, mainly to be exported as raw materials" (Gudynas 2015:13). In these extractivist contexts, rural communities increasingly face environmental deprivation because of encroachment on their territories by diverse and competing interests (Ansoms et al. 2014, Porsani and Lalander 2018).

We rely on a case study of a community in Mozambique (a country that is one such extractivist setting) to scrutinize people's diverse everyday experiences that provide sustenance and meaning to their lives. Accordingly, the main questions orienting our study are as follows. How are livelihoods constructed in the study area? What gender dimensions underpin the social relations that support livelihoods? Why and how is the environment experienced as contributing to or constraining different livelihoods?

In the remainder of this article, we present the study site and methods used. We then describe our findings through gendered livelihood accounts that aim to provide a contextualized view of the uses and relevance of the environment in people's everyday lives. Subsequently, we analyze and discuss what a gendered livelihood perspective reiterates or reveals about experienced ecosystem services. Finally, we conclude by stressing that although there may be better ways of assessing the range of ecosystem services that are not consciously experienced, a gendered livelihood perspective, in most cases, will be useful to the assessment of experienced ecosystem services. We contend that livelihood perspectives can fulfill the normative role of providing a diverse, contextualized, people-centered means of understanding the values of the environment "from below" to make understandings of ecosystem services more representative of, and instrumental to, often neglected local voices and agendas.

\section{STUDY SITE}

Our research site is the rural community of Nguava, situated in the Baixo (Lower) Limpopo Valley in Mozambique, a country with a rural population constituting $64 \%$ of the total population of 28 million (World Bank 2018). In 2017, according to records kept by local authorities, Nguava had 582 inhabitants divided into 96 households. The community belongs to the larger territory of Languene and is located on the west side of the Limpopo River, a floodable and fertile zone between the towns of Xai-Xai and Chicumbane, which have 132,884 inhabitants and 90,451 inhabitants, respectively (República de Moçambique 2017; Fig. $1)$.

Fig. 1. Map of the study area. (A) Baixo (Lower) Limpopo Valley, with the study site, Nguava village, indicated by the black square. (B) Satellite image of Nguava village.

\section{a}

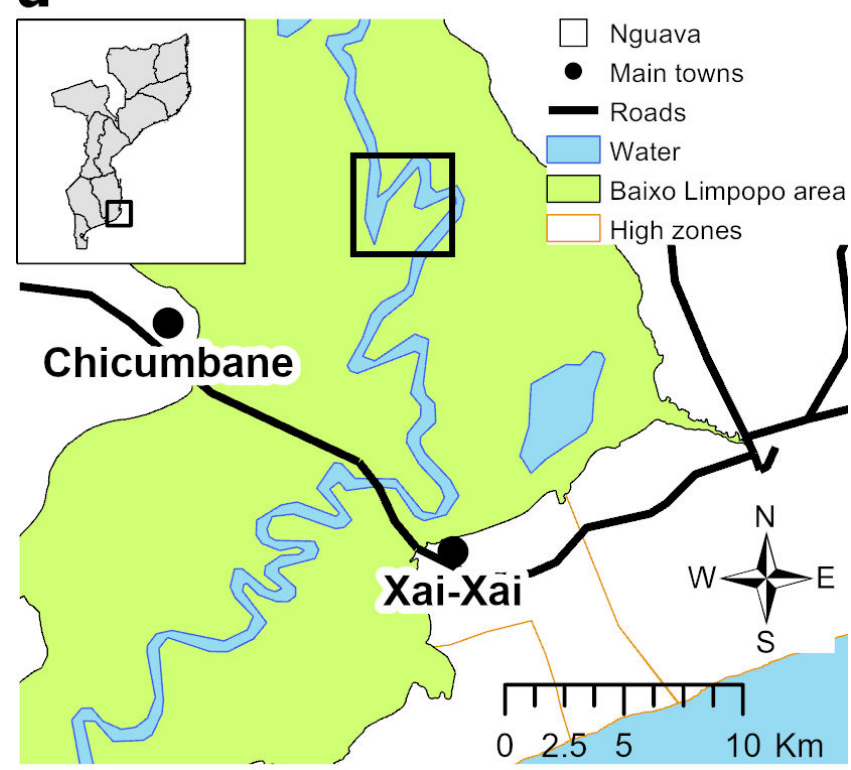

b

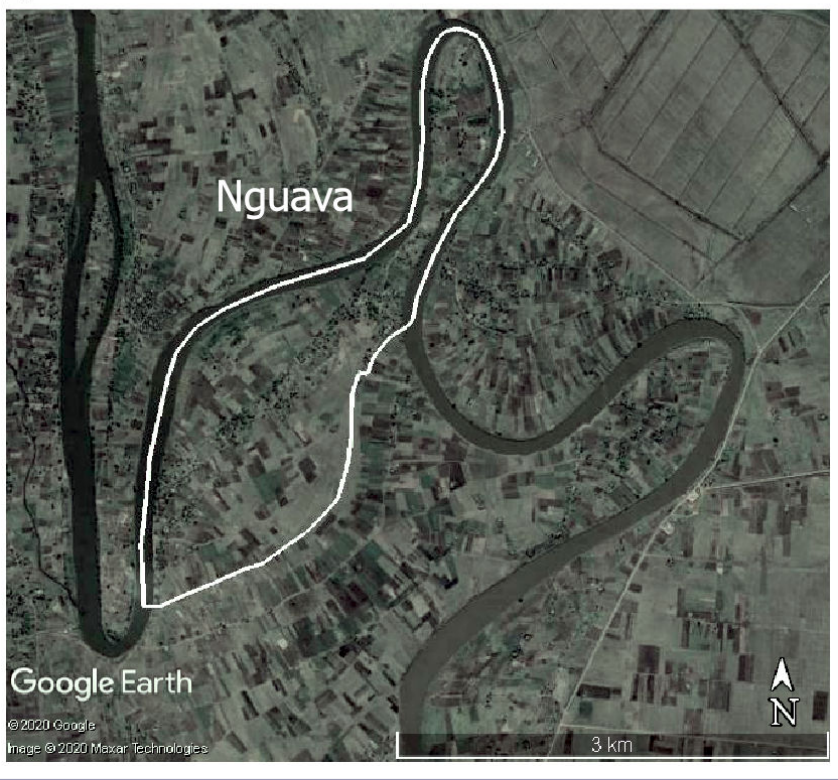


Nguava is located approximately $210 \mathrm{~km}$ from Maputo, the capital of Mozambique, and approximately $10 \mathrm{~km}$ from the main road EN1. Because of the poor quality of the dirt road connecting the village to the main road EN1, a four-wheel drive vehicle is needed to cross it. Alternatively, it takes approximately $2 \mathrm{~h}$ by foot. At EN1, passenger transportation is available through minivans that connect to the nearby towns of Xai-Xai and Chicumbane, where additional destinations are accessible.

The climate of the region is equatorial winter dry (Kottek et al. 2006), with average annual precipitation of $957 \mathrm{~mm}$ (Milhano 2008). Rainfall is concentrated in the summer months of December to March, which makes this period the principal agricultural season. The land cover includes the Limpopo River, oxbow lakes, agricultural land, pastures, and settlements. Nguava's territory is periodically flooded and comprises clayey/ loamy soils that have high organic matter content and are relatively hard to plow manually.

Baixo Limpopo has been a contested area since colonial times, when inhabitants were evicted by Portuguese settlers interested in transforming the area into the granary of southern Africa. During the socialist period, part of the land was transformed to state farms, whereas other areas were reoccupied by Mozambicans. From the late 1980s, when the Mozambican economy started to turn away from central planning and toward a market-led model, and particularly after the end of the civil war in 1992, a new wave of evictions started to take place in Baixo Limpopo and in Mozambique in general (Myers 1994). These evictions followed land concessions to private investors deemed by the government as capable of modernizing agriculture and merging yield gaps (República de Moçambique 2011, 2013). Large-scale land concessions gained international attention after the 2008-2009 world food and financial crisis, amid accusations of land grabs on a global scale (Deininger et al. 2011, GRAIN 2012).

In Baixo Limpopo, in 2012, a Chinese investor secured a land concession of 20,000 ha to produce rice (Porsani et al. 2019). The territory of Nguava lies outside this concession, which allowed us to address the theme of livelihoods in general without having to focus on shocks caused by that project.

\section{METHODS}

Methodologically, instead of asking about the awareness, recognition, or importance of a predefined set of ecosystem services, we relied on participatory livelihood focus groups in which particular analytical attention was placed on gendered human-environmental relations. Livelihood approaches have been intrinsically linked to development practices, and elaborated purposely in contrast to sectoral top-down approaches, to make projects "more consonant with the diverse ways in which people make a living and build their worlds" (Bebbington 1999:2021). Livelihood approaches gained traction in the 1990s, building strongly on participatory methods, household studies, and studies on famine (Chambers and Conway 1992, Solesbury 2003, de Haan and Zoomers 2005).

The scholarly understanding of livelihoods has varied. From being understood first in a more narrow form, i.e., as stocks of flows of food and cash to meet basic needs, or in terms of a person's own capabilities, livelihoods have been successively perceived more broadly as comprising a range of assets, resources, or capitals (commonly divided into physical, human, financial, social, and natural) and activities required for making a living in particular social-environmental contexts (Chambers 1987, Bebbington 1999). In common, definitions tend to portray structures, institutions, and the natural environment as intrinsic parts of contexts and thus as representing opportunities and constraints to different livelihoods. Simultaneously, definitions emphasize agency and thus individuals' varying capacities to lead lives in ways deemed fruitful from their own perspectives. This subjectivity implies an immaterial dimension of livelihoods referent to the meaningfulness of both their means and outcomes, e.g., whether they are desired and deemed appropriate from the perspectives of those undertaking them (Bebbington 1999).

We acknowledge these intertwined material and immaterial dimensions, and understand livelihoods as the following.

- Materially, livelihoods comprise productive and reproductive activities, which use differential asset bases that vary throughout time. Livelihoods take place in specific cultural contexts marked by social-environmentally varying features. They vary among individuals and groups, following their different capacities and means, as well as social norms, anchored on relevant social criteria such as gender, that encourage or discourage specific forms of doing or being.

- Immaterially, livelihoods are intrinsically linked to lifeworlds, or the experiences people have in their everyday lives, and contribute to forming, e.g., identities, views, wishes, and preferences, which altogether contribute to shape how people choose to construct their livelihoods in the first place.

We used a gendered livelihood approach to understand the experienced values of ecosystem services from local perspectives. Such an approach seeks to scrutinize the everyday lives of various social groups (defined in terms of gender and other locally relevant social criteria), with special attention to the roles of the environment. Accordingly, livelihood accounts were our chosen entry point to assess the access, use, and benefits that people derived from the environment. We purposely chose not to make use of rigid livelihood frameworks to avoid imposing "artificial categories and divides [on] how different people in different places live" (Scoones 2009). Instead, open-ended questions constituted entry points for long conversations about subjective everyday experiences. We paid special attention to who experiences what values from the environment, and how, when, where, why, and with which livelihood implications. Central initial questions of our focus group discussions were as follows.

- How do participants spend a typical day/free-time/special times (e.g. different ceremonies)? What do you (they) do? How? Where? When? Why? And with which material and immaterial implications (and to whom). Material implications relate to, for example, the maintenance, expansion, or contraction of production means; immaterial implications relate to, for example, the exercise (or challenge) of social roles, knowledge bases, spiritual beliefs, etc.

- How do the above vary throughout the year in relation to different seasons' labor requirements?

- What changes in times of additional difficulty (e.g., droughts, floods, pests, or household-specific incidents such as disease, death of member, etc.)? 
- How satisfied are participants with their everyday routine and free time, and why? Would they like to do anything different and why? What contributes to or hinders them from improving their conditions?

Different livelihood accounts were gathered through 16 discussion groups. The three variables according to which the groups were composed were gender, marital status, and possession of cattle. These variables were chosen based on previous studies in the region that pointed to gender differences in livelihoods and on conversations with local leaders that signaled the importance of cattle possession in social status. Discussion groups were thus held with local leaders and married men with cattle and married men without cattle; married women with cattle and married women without cattle; and single (widowed or separated) women with cattle and single (widowed or separated) women without cattle. We did not hold discussion groups with single men in Nguava because there was only one man who fell into this category. Focus group members were adults and the heads of their households (or partners). Therefore, focus groups did not include unmarried women and men since these individuals still lived in their parents' households.

Different methods could have been used in the data collection process for livelihood approaches such as observations, unstructured or semistructured individual interviews, and life history interviews, all of which can ground the research in participants' experiences, views, and understandings. Other, more closed, top-down methods such as structured interviews and surveys could also be useful for triangulation. We chose to rely on focus groups mainly because of their interactive nature, wherein the researchers were able to ask for clarifications and make follow-up questions to different people, and participants were able talk to the researchers and each other when building upon or contesting answers. Disagreement was usually a sign that experiences were not widespread among participants, which gave us a chance to investigate the reasons on the spot. These combined properties meant that focus groups yielded elaborated livelihood accounts.

In conducting livelihood approaches, other researchers may be inclined to use other methods because of challenges that can arise in focus group settings. We did, however, find the focus groups to be generative for our objectives. For example, we did not find that participants were reluctant to share their views, but instead found that group settings stimulated individual engagement. Other studies have experienced difficulties ensuring a somewhat balanced engagement of participants due to a tendency for dominant voices to prevail in group settings (most commonly by participants with higher statuses), or have had difficulties keeping control of the research agenda because the influence of the researcher can become more diffused in a group setting (Wilkinson 1998, Smithson 2000). In our study, we found these dynamics to be manageable, and focus groups worked well as a reliable and efficient method for studying livelihoods. Focus groups are considerably more time-saving than individual interviews if we account for the number of individuals with whom we can interact. Our experience is also that it is relatively easier to create a more relaxed atmosphere that stimulates engagement in group a setting, where participants outnumber researchers, than in individual interviews. To foment a friendly and relaxed atmosphere, addressing participants' potential apprehension, we counted on the support from research assistants from the region, allocated enough time for each group session (up to $4.5 \mathrm{~h}$ ), welcomed questions at any time, offered food and soft beverages during breaks, and provided a small gift to each participant at the end of the meeting (usually a bag of sugar, whose price was equivalent to payment for half a day of farm work). To ensure somewhat balanced participation in groups, we selected participants based on specific categories, which yielded a certain homogeneity in the groups. Additionally, when we noticed a tendency for voice domination, we approached it through direct questions to other participants on potential alternative views or experiences. Finally, we found that ceding the control from us, the researchers, to the participants was a positive factor in the group setting because it maximized participants' influence in a study that sought to elicit exactly that, i.e., participants' understandings and experiences.

Thus, because of the above-noted reasons, we found focus groups to be an appropriate method for livelihood approaches. When contemplating other methods, researchers must consider their own skills, resources, time frames, and most importantly, whether these other methods can capture participants' subjective experiences and understandings.

We relied solely on focus groups and on informal conversation with inhabitants. We took notes and recorded all focus group sessions. We analyzed the findings continuously and not only after the conclusion of data collection. Our analysis focused on capturing and understanding local livelihoods and their common or distinct experiences of deriving value from the environment. After each session, we reviewed our notes, discussed the findings, and noted eventual issues that required further clarification. We summarized the group's experiences in text form, which we double-checked with local inhabitants in subsequent focus groups and in informal conversations. Thus, we triangulated the findings by using different data sources rather than different methods (Yin 2003:98).

Data collection took place during July and August 2017. The discussion groups lasted on average $3 \mathrm{~h}$ (range: $1-4.5 \mathrm{~h}$ ) and included three to eight participants from 22 to $>70$ years old (some elderly participants did not know their age). Participants spoke primarily Changana, although some participants also spoke Portuguese and English. The researchers spoke Portuguese and English and relied on assistants who were fluent in Changana and well acquainted with the culture. Before the discussion groups, authorization was secured from the local community leaders. All participants were briefed about the purpose of the research. The conversations were recorded with the permission of the participants. All the material that entered the computer was anonymized and aggregated under group categories.

\section{FINDINGS}

Farming and herding support gendered social relations through synergistic provisioning and spiritual values

Farming is a central livelihood activity in Nguava and in the surrounding Baixo Limpopo Valley. Maize, beans, sweet potato, and pumpkin are cultivated in most fields, whereas lettuce, kale, tomato, garlic, onions, and okra are cultivated on land near the river or lakes (i.e., land that can be quickly manually irrigated). 
Women engage in farming from the start to the end of the two agricultural seasons that take place in the warmer and rainy summer period and in the colder and drier winter period. Men also engage in farming, though usually in activities in which cattle are involved, i.e., plowing the hard clayey soils of the valley. Cattle are instrumental for plowing. Men are responsible for purchasing, rearing, working with, and making decisions about cattle. Sheep and goats are also men's responsibilities. Women are responsible for selling agricultural produce and domesticated birds (e.g., chickens and ducks).

Ideally, households seek to secure enough land (to fulfill food requirements and to be split among sons upon their marriage) and at least two bulls (to pull the plow) and a cow (to procreate). Whereas family land is inherited through patrilineal inheritance, additional land may be obtained from the village chief or by renting or borrowing from acquaintances. Cattle can be obtained in three main ways, all of which are mediated by male labor, which contributes to the establishment of cattle as a "male" asset. First, men may work as herders and receive a calf upon completion of three years of work. Second, men may take care of an acquaintance's female calf, raise it, and breed it. The first-born calf is given to the owner, and the second-born calf remains with the herder, who then returns the now adult cow to the owner. Third, cattle may be purchased. Usually, those who are able to purchase cattle are men who migrate. It is common for migrants who purchase cattle to leave their animals with a friend, which supports the second relationship. It is also possible for men (with access to boats and who are described as serious fishermen) to purchase cattle in parcels.

Land tenure allows individuals to access food (through agricultural produce) and cash (through petty trading of agricultural produce or food and drinks made from produce) and enables relations of exchange of labor, cash, produce, or reciprocal work (day labor). For $5 \mathrm{~h}$ of manual agricultural work, an individual receives 100 meticais (USD \$1.65 according to the average exchange rate in July and August 2017, which, according to the purchasing power parity [PPP] rate of 2017, corresponds to USD \$4.37) or the equivalent in food. Men usually engage in day labor clearing farm fields with machetes, whereas women perform day labor seeding, weeding, and harvesting.

Similarly, cattle generate revenue and additional labor for cattle owners' households. To plow 1 ha, cattle owners charge 2400 meticais (USD \$39.74, or USD \$104.80 PPP); to rent two bulls and a plow for $1 \mathrm{~d}$, cattle owners charge for $2 \mathrm{~d}$ of plowing services. Moreover, cattle enable the transportation of materials (e.g., wood, hay, and reeds) and agricultural produce within the valley and to the high zones, where a share of household members stay during the school year (because there is no secondary-level school in the valley). Cattle also represent a reserve that may be used to fulfill material demands. For example, animals may be sold for the purchase of food and construction material, the payment of medical expenses, and the purchase of a male family member's lobolo (the traditional gift from the groom or his family to the bride's family). Cows with calves likewise provide milk that may be consumed or sold. Thus, cattle are instrumental in fulfilling material livelihood needs at different times (Fig. 2).
Fig. 2. Cattle grazing in a pastoral area.

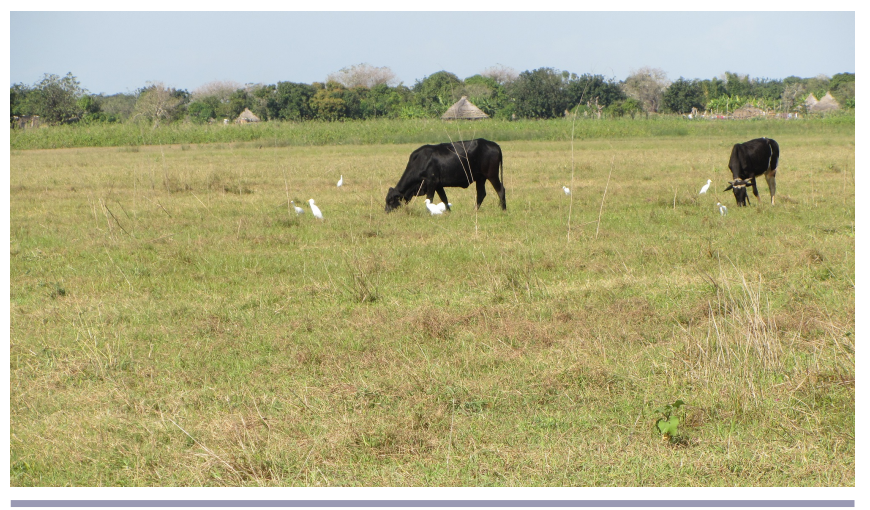

Furthermore, spiritual values are also embodied in land and cattle. Accordingly, family graveyards are usually located under a tree on family land, and both the land and the tree are considered sacred (Fig. 3). Whereas family land is seen as the link between generations, sacred trees are perceived as protecting the spirits that live under them from the sun and the rain.

Fig. 3. A tree surrounded by farm fields.

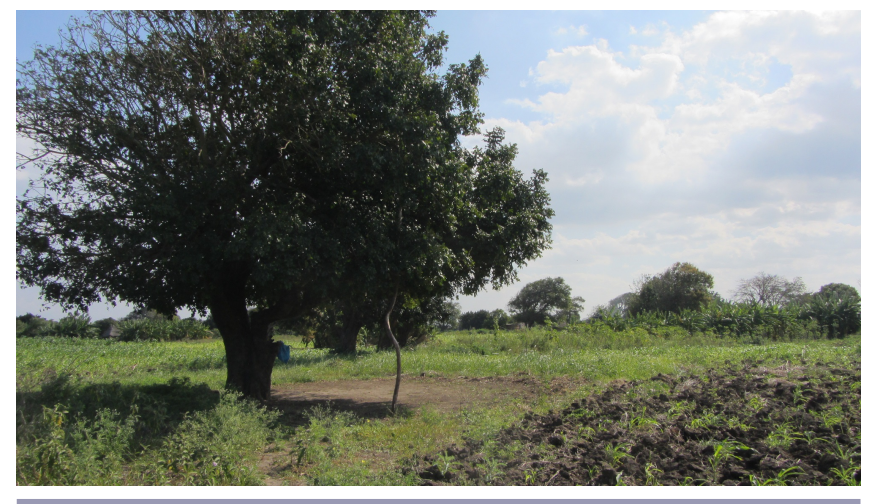

Animals can also be deemed sacred. Sacred animals receive names from important family ancestors and are sacrificed in traditional ceremonies. Cattle, sheep, or goats may be sacrificed in ceremonies that mark, for example, the anniversary of the death of family members. On the first anniversary of the death of a family member, a ceremony is conducted in which the spirit is invited back to the home. An animal is sacrificed in the garden under another sacred tree. The elders of the family honor the spirit of the deceased by offering him or her a part of the animal. After this ceremony, the spirit is believed to be found not only below the sacred tree in the family land but also below the sacred tree in the family's garden.

\section{Complementary productive and reproductive gendered livelihood} activities

In addition to agriculture and cattle herding, other productive and domestic tasks distinguish women's and men's routines. After engaging in farming in the morning, women fetch water, leaves (to make sauces, tea, and medicines), fruits, and fuel to cook with (usually firewood or maize crop residues) on their way home. 
Women whose households own cattle can also use cow dung as fuel, and women with men in their households may also use reeds. Fruits, leaves, and firewood are usually collected from trees in the fields and in their own gardens.

After arriving back at home, women warm up water for their husbands to bathe, and reheat food that they usually have cooked the day before. After eating and resting, women move on to a series of domestic chores: washing dishes and clothes, fetching water from the river up to three additional times, cleaning the home, and pounding and sifting maize in preparation for dinner and the next day's lunch, with the most common dish being a maize porridge known as xima eaten with sauce made from the leaves of produce (most commonly sweet potato, pumpkin, amaranth, manioc, and okra).

As the above account demonstrates, women's productive activities are directly linked to agriculture, and women spend a considerable part of the day engaged in domestic chores. In contrast, men perform several productive activities that are not farm related and spend relatively little time engaged in domestic chores. Men may gather natural assets such as reeds, hay, wood, and bamboo to sell or to use to repair homes, utensils, and furniture. Whereas men are responsible for constructing the house structure and roof (with reeds, wood, and hay), women are responsible for coating the wall structure with a mixture made from soil and cow dung. Reeds are found on the lake and river shores, hay is usually obtained from pastoral zones, and wood and bamboo are usually obtained from people's own lands. Men may sell these materials to neighbors, particularly to women who lack male labor in their households. Men may also engage in hunting, usually of birds. Most small birds can be eaten, and some can be sold for their ornamental value. Although there are crocodiles and hippopotami in the river, hunting these animals is perceived as wrong or illegal (whereas hunting hippopotamus can result in going to jail, hunting crocodile can lead to local reprisals because crocodile brains are believed to contain a poisonous substance that could be used against others).

Late in the afternoon, some men may go fishing. Fishing activity increases in the rainy summer period because of the greater abundance of fish at that time. Those who own boats can fish in the river and sell fish in the region and nearby towns of Xai-Xai or Chicumbane (Fig. 4). Those who own only nets may fish in the lakes of the valley, whereas those with fishing rods are able to fish in both the lakes and river. Fish are commonly donated by fishermen to friends and needy or sick people. In addition to fish, crabs are also found in the river and lakes. Fishing in the river with a rod is considered dangerous because fishermen are constantly exposed to crocodile attacks. Fishing by boat is considered less dangerous because men are exposed to attacks only on their way in and out of the boat. Lakes thus offer safer, though modest, access to fish. Several fish are found in the river and lakes, one of which is black fish (Clarias spp.), a species that plays an important role in local traditional ceremonies. Boats, which are usually made from eucalyptus wood from the region, are also an important transportation means in the everyday lives of Nguavans. Crossing the river usually costs Nguavans 5 to 10 meticais (USD $\$ 0.08-0.16$ or USD $\$ 0.22-0.44$ PPP).
Fig. 4. Boats on the shore of the Limpopo River.

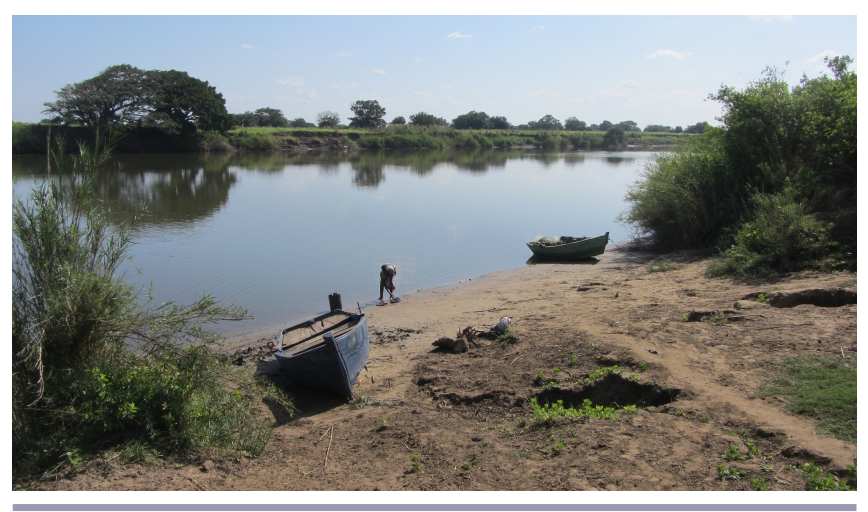

In addition to activities conducted in the valley, migration is also an important activity undertaken by men with varying frequency. Throughout the 1900s, South African mines attracted a large contingent of male migrants from southern Mozambique (Centro de Estudos Africanos 1979, Raimundo 2008). Currently, South Africa is still the main destination of migrants from Nguava, but migrants find occupation mainly in the construction sector instead of the mining sector. Migrants think that, from an economic perspective, it is ideal to spend one year abroad and half a year at home, but most migrants cannot maintain this rhythm due to a lack of capital to travel that often (travel costs include transportation as well as visa and passport costs). Migrants usually raise the money to initiate migration through day labor clearing fields, the sale of natural materials (e.g., reeds, hay, and wood), and the sale of fish and animals (sheep, goats, and cattle). Migrants argue that with the depreciation of the metical in recent years, raising cash for migration has become increasingly difficult. When away, men may send home cash and products (e.g., utensils and clothes) through delivery cars that come to Xai-Xai from South Africa.

During their free time, usually mostly on Sundays, in addition to going to church, most people enjoy visiting friends and families in the valley and in the high zones. There are different churches in Nguava. People who go to the same church meet in the shade of a specific tree. In their free time, people also meet in homes that produce traditional beverages. Traditional beverages are made from local maize and local marula fruits. Ngovo, a drink made from maize, is usually sold, whereas marula drinks are offered as gifts. At the onset of the marula season in February, a large ceremony is held at the village level. The ceremony starts at a tree that is sacred to the region (the Lhilhafani tree), where the spirits of the leaders' ancestors are informed about the festivities (Fig. 5).

The spiritual value of the Lhilhafani tree dates to the founding of Languene's territory, to which Nguava belongs. According to the local historical account, the oldest brother within a family from Chicumbane moved to the valley after a family conflict. As the oldest man in the family, he was responsible for leading the family's traditional ceremonies. After the conflict, he settled in the valley and decided to perform all ceremonies under a large tree (locally called Lhilhafani) using black fish found in the 
Limpopo River. The region was named after him, Nhamalanguene, which was was later shortened by the Portuguese to Languene. It is possible to position the founding of the community historically in the late second half of the $1800 \mathrm{~s}$ based on another historical account that relates an encounter between Nhamalanguene and the last emperor of Gaza, Gungunhane (i.e., the last strong resistance to the colonial state). According to this account, Gungunhane arrived in the region fleeing the Portuguese army. Gungunhane was arrested in December 1895.

Fig. 5. The sacred tree.

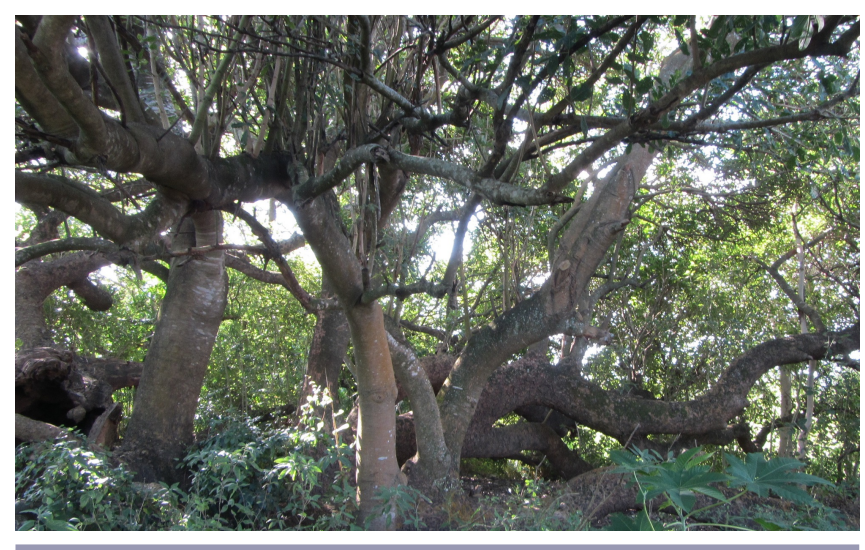

As a testimony of these accounts, the Lhilhafani tree is still alive. It is considered sacred and hosts the common traditional ceremonies performed with fresh black fish (i.e., ceremonies that concern the village or the region as a whole, such as ceremonies against agricultural pests, ceremonies for rain or important funerals, and ceremonies that open important seasons or celebrations). A new "emperor's memorial" stands in front of an old memorial, both built by formal authorities in recognition of the historical value of the region (Fig. 6).

Fig. 6. Memorial for King Gungunhane. It reads, "Here, the king Gungunhane gave his people farewell after being arrested in Chaimite in 1895. Languene, Monument restored in May 2002. Protected by the law $10 / 88$ of December 22, Ministry of Culture".

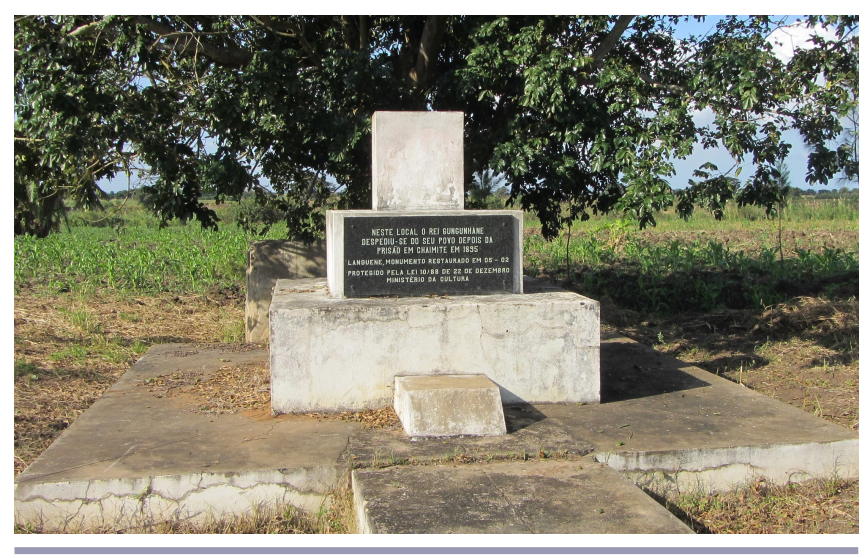

\section{Gender and other central sociodemographic variables}

As indicated, there are general differences among people's livelihoods in Nguava. First and foremost, these differences include gender roles, but also access to important productive assets such as cattle or a boat, which is also largely shaped by gendered relations. The combination of these two dimensions of livelihoods (i.e., gender roles and central productive assets that are usually obtained and maintained through male labor) implies critical livelihood differences between male-headed and femaleheaded households.

Because farmland is passed from father to son according to patrilineal inheritance, women work the land of their fathers and, after marriage, the land inherited by their husbands. Separated women usually return to their original home and live near their relatives, whereas widows continue to work the land of their deceased husband. The well-being of separated women is thus closely related to the well-being of the relatives who provide them with a plot to work, whereas the well-being of widows is more related to their inheritance.

Nonetheless, separated women and widows generally tend to depend on voluntary help or purchased services from men to complete activities that fall into the domain of masculinity, whereas married women can rely on the complementary labor of their husband (e.g., clearing new fields, collecting construction materials, repairing the house, fishing, and plowing with bulls). Accordingly, separated women or widows tend to have worse access than married women to cash derived from male activities (e.g., from the sale of natural materials and fish, working with cattle, and migration). Therefore, purchasing everyday industrialized products such as sugar, salt, peanuts (used in sauces), oil, matches, kerosene for lighting, soap, school materials, and clothes, in the towns of Xai-Xai and Chicumbane is considerably more difficult for women heads of household. Thus, households headed by women tend to face not only a relative lack of male labor but also a relative lack of capital, with access to capital often being restricted to women's day labor on other farms, the sporadic sale of birds (chickens and ducks), and the limited sale of agricultural produce or derived products.

To cultivate land despite not having cattle, women may purchase bull-driven plowing services in exchange for their own labor. Therefore, women may reduce the drudgery of manually plowing the hard clayey soils of the valley to the relatively easier activity of weeding. Women entering this exchange must work 24 mornings in another field to pay for the plowing of 1 ha (i.e., 2400 meticais to plow 1 ha and 100 meticais per morning of manual work). Widows who are left without cattle, just as separated women who return to households that do not own cattle, thus become the most vulnerable. Often, these women may need either to plow their fields manually with a hoe or to cultivate them to a lesser extent because they are more likely to lack the money needed to pay for bull plowing and to lack the time to pay for the plowing service with their own labor.

The situation is relatively more favorable for widows who are left with important productive assets. If a widow is left with a boat, although she will most likely not fish herself, she may rent the boat to a man under different agreements (e.g., the provision of fish or cash). If a widow is left with cattle, she may leave the animals under the care of a male from her family or another family 
under a contract. She may also enter agreements with other men interested in plowing their own fields with her cattle and, in turn, receive labor, cash, or equivalent produce. The inheritance of assets, as well as the ties between widows or separated women with other males (e.g., adult sons or contracted men who may perform the activities that are considered to be masculine), contribute to important livelihood differences among households that are female-headed. Nonetheless, the fact that these central assets are usually purchased with male income implies that if widows lose them (e.g., a loss of cattle due to an epidemic or flooding), they will most likely not be able to reestablish their previous conditions.

\section{Livelihoods in difficult times}

As the livelihood descriptions show, livelihoods in Nguava are diverse. Understanding the diversity within Nguava is critical to avoid homogenizing the "people" or "the locals" of Nguava. In general, this diversity can be largely explained through intertwined gender and economic conditions. In addition, these two criteria interact with different marital status conditions. These differences create diverse everyday livelihood alternatives and mediate individuals' access to alternatives in difficult times.

In addition to household-specific occurrences (e.g., the disease or death of a member), there are common generalized sources of livelihood impairment. Pests that attack agriculture are recurrent. Maize stem borer (Chilo partellus), African black beetle (Heteronychus arator), and grasshoppers are the most threatening. Rats and hippos (the latter of which destroy fields close to the river) also impair livelihoods. After harvest, produce has been threatened by maize weevil (Sitophilus zeamais). The locally used means of combating pests include traditional ceremonies with the sacred Lhilhafani tree and black fish. Ceremonies to combat agricultural pests, known as phophani, involve women walking the fields barefoot, collecting samples of the pests and swearing at them. These samples are gathered under a sacred tree and burned by elders and leaders.

Cattle and other ruminants are also affected by diseases. Threatening vectors include ticks, which cause open wounds that become contaminated by flies and larvae, weakening the animal considerably; flies that can affect the animals' eyes, leading to blindness; and poisonous insects that kill animals. Animals can also be affected by periodic epidemics that cause fever, diarrhea, and death. To tackle tick-borne diseases, baths against ticks have been organized by official agricultural authorities. Leaves and latex from local plants are used to treat animals' wounds and infected eyes.

Two additional phenomena recurrently challenge livelihoods: the flooding of the Limpopo and droughts (described as a lack of sufficient rain to sustain agriculture in a specific season). There have been "normal" floods and massive floods in Nguava's history. Normal floods usually damage some of the fields but do not force all individuals and their animals to relocate to the high zones. In contrast, massive floods affect the entire valley, killing humans and animals in the region. There have been two floods that were considered massive floods by Nguavans in relatively recent times, one in 1977 and one in 2000.

When Nguavans leave the valley to flee floods, they go to the high zones, either to the homes of family relatives or their own secondary homes (the government provided housing in the high zones for the inhabitants of the valley following the floods of 1977 and 2000). Nguavans take their produce on their backs or heads or with the help of cattle or boats. The question of whether to transport animals is challenging because there is little area for cattle in the high zones. Animals usually stay in common corrals, where there are increased risks of theft and diseases. Therefore, in 2000, several cattle owners ignored governmental warnings and stayed in the valley with the cattle. This decision resulted in the drowning of a large number of ruminants and in people having to be rescued from treetops by helicopters.

When in the nearby cities of Chicumbane or Xai-Xai (i.e., the high zones), individuals in need of immediate cash or food may engage in day labor in the fields located in these high zones. Because the soils in these zones are sandy and can be worked relatively easily without the help of bull-driven plows, women can perform all the farming work. Women may also earn cash by cleaning the gardens and homes of other households (washing clothes, cooking, etc.). Additionally, surplus produce may be sold, animals may be sold or exchanged for food, and boat owners may fish for consumption and sale.

During droughts, individuals usually stay in the valley. All saved produce and even seeds are consumed. Animals may also be sold or exchanged for food. Feeding animals during droughts is challenging because a lack of rain impairs pastures. When pastures are insufficient, cattle, goats, and sheep may eat leaves from trees (e.g., eucalyptus) and, in the worst cases, even reeds. Fishing becomes a relatively important source of food. Demand for agricultural day labor becomes very limited. Men may gather natural construction materials to sell in the high zones. During droughts (and floods), migrant men may send cash and food. A common source of nutrition during droughts (and after floods when individuals return to the valley, oftentimes with no produce left), which is referred to as an emergency asset, is the leaves of the wild-growing tsinguasinguane (Ipomoea sp.) for sauce, which is eaten with water lily tubers known as matevhu (Nymphaea lotus; Fig. 7).

Fig. 7. Water lilies in a lake

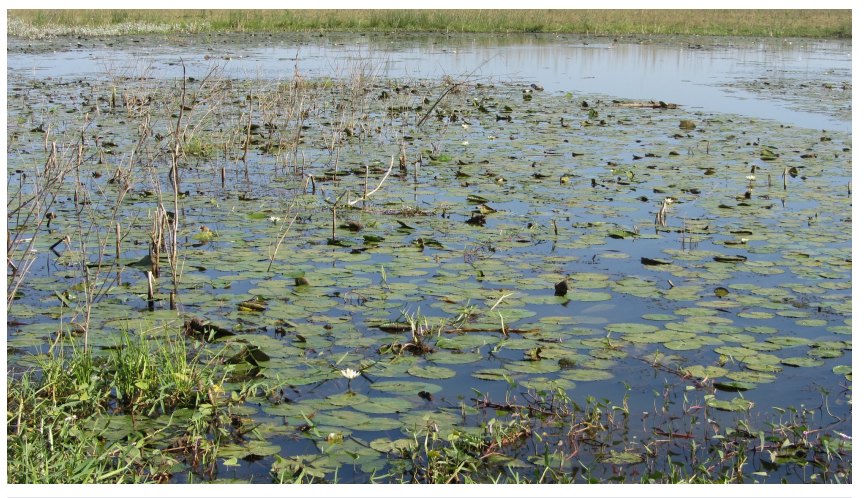

Depending on the time of year, fruits from different species may be available. Mafura (Trichilia emetica) and mango are particularly important trees nutritionally. Fruits are usually not sold but rather consumed by household and family members or given to friends. Individuals may also find small animals such as 
rats caught in the fields, wild chickens and other wild birds, frogs found in the lakes, and salamanders, to complement their diets, particularly in more difficult times.

\section{DISCUSSION}

To return to our theoretical-methodological challenge, that is, regarding the value of a gendered livelihood approach to ecosystem services research, the descriptions above are not exhaustive but show the diversity of livelihoods in the small community of Nguava. Understanding this diversity is a constituent part of unpacking "the locals" and consequently answering the questions of "Ecosystem services for whom?" and "Who benefits from ecosystem services?" (Barnaud and Antona 2014, Bennett et al. 2015).

Why should we answer these questions through an approach that contextualizes ecosystem services in livelihoods? Further, why should gender be an important analytical parameter? As we will show with the examples following, a livelihood contextualization of ecosystem services can help avoid a range of shortcomings, such as:

- Ignoring social heterogeneity or approaching it in a simplistic fashion that cuts short the linkages between social groups and their ecosystem-based productive and reproductive activities. This effect is illustrated by studies that: (1) ignore social heterogeneity by not acknowledging the varying experiences of different social groups in relation to ecosystem services and therefore address "communities" as one entity or as single stakeholders or beneficiaries of common ecosystem services (Maass et al. 2005, Agbenyega et al. 2009, Nahuelhual et al. 2016); (2) acknowledge heterogeneity solely in a contrasting position manner, e.g., what has value to women vs. men, women's vs. men's knowledge or awareness of ecosystem services, etc. (MartínLopez et al. 2012, Tadesse et al. 2014, Mensah et al. 2017); or (3) acknowledge heterogeneity but focus on a single group, potentially ignoring the experiences of deemed nongroup members (Tauro et al. 2018).

- Ignoring plural values (e.g., bundles of ecosystem services and social relations) that may cross-cut predefined value categories, as illustrated by studies that: (1) identify a priori which ecosystem services may be valuable, possibly missing different experiences of the same or other ecosystem services, experiences which likely vary among groups on regular or irregular bases due to, e.g., seasonal changes, floods, droughts, or pests (Zhang et al. 2016); or (2) address only one ecosystem service (Reed et al. 2017), possibly ignoring not only bundles of ecosystem services but also how ecosystem services, by feeding different livelihood activities, enable dynamic and asymmetrical, and thus power-laden, social relations.

- Missing the cultural embeddedness of all experienced ecosystem services, as illustrated by studies that: (1) understand ecosystem services solely as benefits generated by the environment to humans, ignoring human interactions that coproduce experienced ecosystem services (Maes et al. 2012); or (2) classify ecosystem services into distinct categories, one of which is cultural (Boafo et al. 2016).
Altogether, these tendencies risk yielding partial views on how the environment is experienced from local perspectives. This partiality hampers the comprehensive understanding of how gender intersects with ecosystem services because gender is necessarily relational and contextual. Therefore, gender relations cannot be understood fully or accurately through approaches that overlook how people live their everyday lives. Whereas other criteria, for example, wealth, occupation, caste, ethnicity, religion, and age, may also be relevant in other contexts (Rönnbäck et al. 2007, Hamann et al. 2016, Brown and Fortnam 2018), in patriarchal rural communities in developing countries, where gender norms strongly mediate livelihoods, gender is critical in defining the differential benefits that people experience from the environment. Not seldom, gender intersects with wealth, resulting in the latter becoming, to a large extent, a variable that is dependent on the former (Fonjong 2008, Yemiru et al. 2010, Perez et al. 2015).

In Nguava, the confluence of gender and economic status is central to the relations people establish with the environment and consequentially to the relative benefits that people obtain from it. Accordingly, although farming underpins all livelihoods, it holds a particularly critical value for women with fewer incomegenerating livelihood alternatives. Additionally, cattle constitute a strategic productive asset that indicates higher social status and falls strongly under the realm of masculinity. Whereas fishing and the harvesting of natural construction materials (e.g., reeds, hay, and wood) are considered male activities, farming, along with an array of daily domestic activities, falls in the woman's realm. Migration is also a gendered activity that is mainly available to men. In line with our findings, other studies have shown that African women and female-headed households are relatively more vulnerable, cash-deprived, and consequently, more dependent on environmental assets than men and male-headed households (Fonjong 2008, Yemiru et al. 2010, Kalaba et al. 2013, Perez et al. 2015). Hence, an important observation is that a gendered livelihood approach to ecosystem services will often reach beyond questions of gender toward understandings of how gendered experiences intersect, for example, with processes of wealth accumulation, i.e., through differentiated access to productive assets and the differentiation of productive and domestic labor.

The varying reliance of gendered livelihoods on the environment reinforces the idea that experienced values are not fixed but relative, differing among social groups as well as over time. Accordingly, wild plants in Nguava are critical assets for most households during difficult times, and fish become a strategic asset, controlled mainly by fishermen with boats, during floods and droughts. A livelihood approach to ecosystem services elucidates the contingency and the dynamism of values embodied in the environment. Furthermore, whereas a gendered approach to ecosystem services reveals differences between how men and women use the environment, a livelihood approach shows that arguments that sharply separate what has value to women vs. men fall short regarding the more complex social-ecological dynamics of not only the interdependence and complementarity of different activities but also what is known in ecosystem services studies as bundling (of ecosystem services) and relational environmental values (Martín-López et al. 2012, Tadesse et al. 2014, Mensah et al. 2017). 
A livelihood approach reinforces the view that the environment delivers plural, rather than single, values that cross-cut value categories (i.e., bundles of values; Raudsepp-Hearne et al. 2010, Chan et al. 2012b). Accordingly, whereas trees may have different provisioning values (e.g., through fruits, leaves, and wood) to different user groups, they may also represent the homes of ancestors to a family or an entire community. Likewise, black fish are not only a source of food and income but also represent a link between community inhabitants and the spirits of the community founders in traditional ceremonies. Because both provisioning and spiritual values are embedded in the same objects in these cases, it would be inadequate to conclude that trees or fish are more valuable to either women or men. The bundling or conflation of values derived from the environment is particularly important in contexts such as in Nguava, where the spiritual world is held as an intermediary in the material success of individuals. In such contexts, a failure to understand the plurality of values or a fear of double-counting them (de Groot et al. 2002) leads to incomplete views that are not representative of local lifeworlds (Cooper et al. 2016).

Additionally, the livelihoods of Nguavans reveal that the values of ecosystem services are derived not only from outputs from the environment but also from the social and fundamentally gendered relations (i.e., relational values) that are established among people and between people and the environment in the process of maintaining or obtaining outputs perceived as valuable, combating outputs perceived as harmful, and using outputs in other activities. Accordingly, when farming, women exercise their identities as farmers, as providers of food to their households, and as the current caretakers of the land that was cultivated by a chain of women before them (Chan et al. 2012a).

Furthermore, when farming (women with their hands and hoes and men with their bulls and plows), individuals engage in agricultural practices that are anchored in particular knowledge systems and shaped by gendered social roles and rules of access (e.g., access to land, labor, and productive assets). Economic relations are also enabled by farming, for example, day labor that connects households that need additional workers with those that need immediate cash or food. When agriculture is threatened by pests or the delay of rain, Nguavans rely on a specific belief system to conduct ceremonies that call upon spiritual values related to their ancestors' intervention in the earthly world. When agricultural produce is obtained, further relations take shape: women transform part of the produce into food, and they save, sell (exchange), or donate the rest.

Accordingly, subsequent and multiple values are derived from these relations, i.e., not only provisioning and economic values but also the nurturing of social ties and of senses of place and home (which is particularly important for women who move to different communities upon marriage), the exercise of belief and knowledge systems, and the exercise or challenging of social roles and norms (e.g., gender roles and access norms), among other values. Similar to farming, activities and relations precede and follow other livelihood activities that ensure the differential reproduction and production of households. For example, in relation to fishing, boats are constructed, loaned, and sold; arrangements of exchanges between fish and other assets are established; fish are consumed by families, sold (exchanged), or donated; and black fish are used in traditional ceremonies.
A focus on relations preceding and following outputs from the environment reinforces the view that ecosystem services are not simply delivered but result from more or less intensive humanenvironmental interaction that takes place in contexts that are fundamentally cultural. Therefore, a livelihood approach stresses the necessary coproduction of experienced ecosystem services by the environment and human agency embedded in culture (Lele 2013, Jackson and Palmer 2015, Jones et al. 2016, Kenter 2018, Raymond et al. 2018). If we accept this view, the difference between a farmer's maize harvest and fruits from an individual's garden or between the water fetched by women and the reeds cut by men is simply one of intensity or the manner of interaction with the environment.

Thus, widening the analytical scope to gendered livelihoods, rather than only outputs or services from the environment, exposes value-laden relations that build on ecosystem services and tend to become hidden in assessments that disregard livelihoods in their entirety. These relations reveal a web of interdependency within and among social groups that is by no means regular or equal. In contrast, the exposed relations are often substantiated by asymmetrical conditions. This situation is comprehensible because livelihoods are embedded in structures of differential power and are therefore never power-neutral but rather "engender processes of inclusion and exclusion" (de Haan and Zoomers 2005:34). Accordingly, different livelihoods rely differently on the environment as well as each other. For example, households lacking cattle depend on households owning cattle and owe them either cash or services.

A focus on gendered livelihoods allows us to unveil the everyday practices through which ecosystem services feed but also possibly challenge the status quo at different levels while contributing to contextualizing the relative and dynamic values embodied in the environment. These values transcend materiality, which is illustrated by the generalized strategy of seeking the support of the spirits of family and community ancestors to eradicate pests. The essentiality of sacred trees and black fish in traditional ceremonies also illustrates the intrinsic connection between the earthly and spiritual worlds, or better put, the inseparably earthlyspiritual world.

Finally, understanding gendered livelihoods in relation to ecosystem services also has conceptual implications for livelihood frameworks that tend to depict all that is valuable and is derived from the environment as "natural capital", defined by Scoones as "the natural resource stocks (soil, water, air, genetic resources, etc.) and environmental services (hydrological cycle, pollution sinks, etc.) from which resource flows and services useful for livelihoods are derived" (Scoones 1998:7). As Nguavans' experiences show, the environment feeds into everyday relations that transform natural assets or capital into economic and physical capital through relations that build on and have implications for social and human capital (to use livelihood nomenclature). For example, as men work with reeds, human capital is exercised and spread; reeds subsequently become physical capital in construction or economic capital when sold. Additionally, reeds can nurture social capital in different ways, for instance, when being donated or when used to construct common infrastructure and buildings.

These links, which are particularly clear in rural communities that rely substantially on the near environment, elucidate how 
misleading it can be to confine the environment to one building block of livelihoods when the environment is embedded in culture and pervades people's lifeworlds. These links also reiterate that culture is wherever humans are, and therefore, all experienced contributions from the environment are also fundamentally cultural (Chan et al. 2012a, Díaz et al. 2018). A gendered livelihood approach leaves no doubt about the cultural embeddedness of activities and values.

\section{CONCLUSIONS}

Anchored in a case study in a community in rural Mozambique, where the environment is central to people's everyday lives in diverse, dynamic, and material and immaterial ways, our study stresses the relevance of gendered livelihood perspectives as entry points to understanding by whom, how, when, and why the environment is experienced as valuable. Livelihood perspectives are about "how different people in different places live" (Scoones 2009). Thus, livelihoods unfold as individuals engage in everyday activities that yield not only material instrumental sustenance but also meaning for local lifeworlds.

Although the descriptions presented and analyzed here are particular to Nguava, they provide insights that are applicable to other communities where patriarchal norms substantiate livelihoods and insights into ecosystem services research as a whole. In the extractivist context that increasingly characterizes the natural resource-abundant Global South, we believe that elucidating and reasserting bundling, relativeness in relation to cross-cutting categories, dynamism, cultural embeddedness, and the consequential incompleteness of numerical valuations of ecosystem services, and likewise of compensatory measures for land grabbing, are critical and timely tasks that should animate collaboration beyond disciplinary boundaries.

Gendered livelihood perspectives stress that for understandings of ecosystem services to have any correspondence with what is subjectively experienced in particular contexts, values (i.e., what is experienced as ecosystem benefits) should: (1) be disaggregated based on locally meaningful criteria; (2) account for bundling, contingency, and dynamism; and (3) acknowledge asymmetrical social relations that precede and follow environmental outputs. These three points are critical to understand experienced ecosystem services and the gender dimension of ecosystem services holistically and to challenge numerical valuations by considering elements that resist commodification (e.g., experiences of identity, place, home, and spiritual significance). Consequently, a gendered livelihood approach to ecosystem services implies that compensation and substitution for land or environmental loss are inevitably limited because incommensurable value is irrevocably lost.

Importantly, gendered livelihood perspectives do not presume that cultures are static; in contrast, accounts of livelihoods can reveal continuous changes in relation to the wider socioeconomic environment. Likewise, they do not imply cultural romanticism or the idea that some pristine cultures should be preserved; instead, an understanding of how the environment is experienced and valued in local social relations of production and reproduction contributes to showing that cultures do not necessarily work equally in favor of all members, which is clear in patriarchal communities.
Most importantly, in focusing on the experienced gender dimension of ecosystem services, livelihood perspectives fulfill the normative role of providing a people-centered means to assess the values of the environment "from below". They thereby stress the centrality of open and inclusive accounts that contextualize the environment in people's lifeworlds, making understandings of ecosystem services more representative of, and instrumental to, people's voices and agendas. Whereas in patriarchal communities, gender is a central defining factor of social relations, other social attributes (often entangled with gendered relations) such as wealth are also relevant. In different contexts, other social features such as caste, ethnicity, religion, and age may be equally or more central to the understanding of ecosystem services in relation to livelihoods. Additionally, livelihood perspectives do not exclude other forms of assessment. Whereas bottom-up participatory methods are critical to understand local experiences, these methods could be complemented with structured interviews to allow for quantitative gendered analysis. Moreover, top-down or collaborative methods based on external expertise may be more appropriate to assess environmental functions that are not always consciously experienced in particular contexts by different social groups.

Finally, differentiated livelihood perspectives on ecosystem services imply that subjective experiences can be objectively explained and understood. It is the understanding of multiple, variable, and dynamic values embodied in the environment that is central for the comprehension of whose livelihoods are at stake and why they are at stake when the environment becomes a contested matter.

Responses to this article can be read online at: http://www.ecologyandsociety.org/issues/responses. php/11781

\section{Acknowledgments: \\ We thank the interviewees for participating. We also thank the Swedish Society for Anthropology and Geography and the foundation Forskraftstiftelsen Theodor Adelswärds Minne for funding of fieldwork.}

\section{Data Availability:}

The datalcode that support the findings of this study are available on request from the corresponding author, JP. The datalcode are not publicly available to safeguard the anonymity of research participants.

\section{LITERATURE CITED}

Agbenyega, O., P. J. Burgess, M. Cook, and J. Morris. 2009. Application of an ecosystem function framework to perceptions of community woodlands. Land Use Policy 26(3):551-557. https:// doi.org/10.1016/j.landusepol.2008.08.011

Ansoms, A., I. Wagemakers, M. M. Walker, and J. Murison. 2014. Land contestation at the micro scale: struggles for space in the African marshes. World Development 54:243-252. https://doi. org/10.1016/j.worlddev.2013.08.010 
Barnaud, C., and M. Antona. 2014. Deconstructing ecosystem services: uncertainties and controversies around a socially constructed concept. Geoforum 56:113-123. https://doi. org/10.1016/j.geoforum.2014.07.003

Bebbington, A. 1999. Capitals and capabilities: a framework for analyzing peasant viability, rural Livelihoods and poverty. World Development 27(12):2021-2044. https://doi.org/10.1016/S0305-750X (99)00104-7

Bennett, E. M., W. Cramer, A. Begossi, G. Cundill, S. Díaz, B. N. Egoh, I. R. Geijzendorffer, C. B. Krug, S. Lavorel, E. Lazos, L. Lebel, B. Martín-López, P. Meyfroidt, H. A. Mooney, J. L. Nel, U. Pascual, K. Payet, N. Pérez Harguindeguy, G. D. Peterson, Anne-Hélène Prieur-Richard, B. Reyers, P. Roebeling, R. Seppelt, M. Solan, P. Tschakert, T. Tscharntke, B. L. Turner II, P. H. Verburg, E. F. Viglizzo, P. C. L. White, and G. Woodward. 2015. Linking biodiversity, ecosystem services, and human well-being: three challenges for designing research for sustainability. Current Opinion in Environmental Sustainability 14:76-85. https://doi. org/10.1016/j.cosust.2015.03.007

Boafo, Y. A., O. Saito, G. S. Jasaw, K. Otsuki, and K. Takeuchi. 2016. Provisioning ecosystem services-sharing as a coping and adaptation strategy among rural communities in Ghana's semiarid ecosystem. Ecosystem Services 19:92-102. https://doi. org/10.1016/j.ecoser.2016.05.002

Brown, K., and M. Fortnam. 2018. Gender and ecosystem services: a blind spot. Pages 257-272 in K. Schreckenberg, G. Mace, and M. Poudyal, editors. Ecosystem services and poverty alleviation: trade-offs and governance. Routledge, London, UK.

Centro de Estudos Africanos. 1979. O mineiro moçambicano: um estudo sobre a exportação de mão de obra em Inhambane. Universidade Eduardo Mondlane, Maputo, Mozambique.

Chambers, R. 1987. Sustainable livelihoods, environment and development: putting poor rural people first. IDS Discussion Paper 240. Institute of Development Studies, Brighton, UK. [online] URL: https://opendocs.ids.ac.uk/opendocs/handle/20.500.12413/875

Chambers, R., and G. R. Conway. 1992. Sustainable rural livelihoods: practical concepts for the 21st century. IDS Discussion Paper 296. University of Institute of Development Studies, Brighton, UK. [online] URL: https://www.ids.ac.uk/publications/ sustainable-rural-livelihoods-practical-concepts-for-the-21st-century/

Chan, K. M. A., A. D. Guerry, P. Balvanera, S. Klain, T. Satterfield, X. Basurto, A. Bostrom, R. Chuenpagdee, R. Gould, B. S. Halpern, N. Hannahs, J. Levine, B. Norton, M. Ruckelshaus, R. Russell, J. Tam, and U. Woodside. 2012a. Where are cultural and social in ecosystem services? A framework for constructive engagement. Bioscience 62(8):744-756. https://doi.org/10.1525/ bio.2012.62.8.7

Chan, K. M. A., T. Satterfield, and J. Goldstein. $2012 b$. Rethinking ecosystem services to better address and navigate cultural values. Ecological Economics 74:8-18. https://doi. org/10.1016/j.ecolecon.2011.11.011

Cooper, N., E. Brady, H. Steen, and R. Bryce. 2016. Aesthetic and spiritual values of ecosystems: recognising the ontological and axiological plurality of cultural ecosystem 'services'. Ecosystem Services 21(B):218-229. https://doi.org/10.1016/j.ecoser.2016.07.014
Cruz-Garcia, G. S., E. Sachet, G. Blundo-Canto, M. Vanegas, and M. Quintero. 2017. To what extent have the links between ecosystem services and human well-being been researched in Africa, Asia, and Latin America? Ecosystem Services 25:201-212. https://doi.org/10.1016/j.ecoser.2017.04.005

Daw, T., K. Brown, S. Rosendo, and R. Pomeroy. 2011. Applying the ecosystem services concept to poverty alleviation: the need to disaggregate human well-being. Environmental Conservation 38 (4):370-379. https://doi.org/10.1017/S0376892911000506

Daw, T. M., S. Coulthard, W. W. L. Cheung, K. Brown, C. Abunge, D. Galafassi, G. D. Peterson, T. R. McClanahan, J. O. Omukoto, and L. Munyi. 2015. Evaluating taboo trade-offs in ecosystems services and human well-being. Proceedings of the National Academy of Sciences 112(22):6949-6954. https://doi.org/10.1073/ pnas. 1414900112

de Groot, R. S., M. A. Wilson, and R. M. J. Boumans. 2002. A typology for the classification, description and valuation of ecosystem functions, goods and services. Ecological Economics 41(3):393-408. https://doi.org/10.1016/S0921-8009(02)00089-7

de Haan, L., and A. Zoomers. 2005. Exploring the frontier of livelihoods research. Development and Change 36(1):27-47. https://doi.org/10.1111/j.0012-155X.2005.00401.X

Deininger, K., D. Byerlee, J. Lindsay, A. Norton, H. Selod, and M. Stickler. 2011. Rising global interest in farmland: Can it yield sustainable and equitable benefits? World Bank, Washington, D. C., USA. [online] URL: https://openknowledge.worldbank.org/ handle/10986/2263

Díaz, S., U. Pascual, M. Stenseke, B. Martín-López, R. T. Watson, Z. Molnár, R. Hill, K. M. A. Chan, I. A. Baste, K. A. Brauman, S. Polasky, A. Church, M. Lonsdale, A. Larigauderie, P. W. Leadley, A. P. E. van Oudenhoven, F. van der Plaat, M. Schröter, S. Lavorel, Y. Aumeeruddy-Thomas, E. Bukvareva, K. Davies, S. Demissew, G. Erpul, P. Failler, C. A. Guerra, C. L. Hewitt, H. Keune, S. Lindley, and Y. Shirayama. 2018. Assessing nature's contributions to people. Science 359(6373):270-272. https://doi. org/10.1126/science.aap8826

Folke, C., C. Fabricius, G. Cundill, and L. Schulze. 2005. Communities, ecosystems, and livelihoods. Pages 261-277 in D. Capistrano, C. Samper, M. J. Lee, and C. Raudsepp-Hearne, editors. Ecosystems and human well-being: multiscale assessments, volume 4. Island Press, Washington, D.C., USA. [online] URL: https://www.millenniumassessment.org/documents/document.349. aspx.pdf

Fonjong, L. N. 2008. Gender roles and practices in natural resources management in the north west province of Cameroon. Local Environment 13(5):461-475. https://doi.org/10.1080/13549$\underline{830701809809}$

GRAIN. 2012. GRAIN releases data set with over 400 global land grabs. GRAIN, Barcelona, Spain. [online] URL: https://www. grain.org/article/entries/4479-grain-releases-data-set-with-over-400global-land-grabs

Gudynas, E. 2015. Extractivismos: ecología, economía y política de un modo de entender el desarrollo y la naturaleza. CLAES and CEDIB, Cochabamba, Bolivia. 
Hamann, M., R. Biggs, and B. Reyers. 2016. An exploration of human well-being bundles as identifiers of ecosystem service use patterns. Plos One 11(10):e0163476. https://doi.org/10.1371/ journal.pone. 0163476

Jackson, S., and L. R. Palmer. 2015. Reconceptualizing ecosystem services: possibilities for cultivating and valuing the ethics and practices of care. Progress in Human Geography 39(2):122-145. https://doi.org/10.1177/0309132514540016

Jones, L., L. Norton, Z. Austin, A. L. Browne, D. Donovan, B. A. Emmett, Z. J. Grabowski, D. C. Howard, J. P. G. Jones, J. O. Kenter, W. Manley, C. Morris, D. A. Robinson, C. Short, G. M. Siriwardena, C. J. Stevens, J. Storkey, R. D. Waters, and G. F. Willis. 2016. Stocks and flows of natural and human-derived capital in ecosystem services. Land Use Policy 52:151-162. https:// doi.org/10.1016/j.landusepol.2015.12.014

Kalaba, F. K., C. H. Quinn, and A. J. Dougill. 2013. Contribution of forest provisioning ecosystem services to rural livelihoods in the Miombo woodlands of Zambia. Population and Environment 35:159-182. https://doi.org/10.1007/s11111-013-0189-5

Kenter, J. O. 2018. IPBES: Don't throw out the baby whilst keeping the bathwater; put people's values central, not nature's contributions. Ecosystem Services 33(A):40-43. https://doi. org/10.1016/j.ecoser.2018.08.002

Kottek, M., J. Grieser, C. Beck, B. Rudolf, and F. Rubel. 2006. World map of the Köppen-Geiger climate classification updated. Meteorologische Zeitschrift 15(3):259-263. https://doi. org/10.1127/0941-2948/2006/0130

Lele, S. 2013. Environmentalisms, justices and the limits of ecosystem services frameworks. Pages 119-139 in T. Sikor, editor. The justices and injustices of ecosystem services. Routledge, London, UK.

Maass, J. M., P. Balvanera, A. Castillo, G. C. Daily, H. A. Mooney, P. Ehrlich, M. Quesada, A. Miranda, V. J. Jaramillo, F. GarcíaOliva, A. Martínez-Yrizar, H. Cotler, J. López-Blanco, A. PérezJiménez, A. Búrquez, C. Tinoco, G. Ceballos, L. Barraza, R. Ayala, and J. Sarukhán. 2005. Ecosystem services of tropical dry forests: insights from long-term ecological and social research on the Pacific coast of Mexico. Ecology and Society 10(1):17. https:// doi.org/10.5751/ES-01219-100117

Maes, J., B. Egoh, L. Willemen, C. Liquete, P. Vihervaara, J. P. Schägner, B. Grizzetti, E. G. Drakou, A. La Notte, G. Zulian, F. Bouraoui, M. L. Paracchini, L. Braat, and G. Bidoglio. 2012. Mapping ecosystem services for policy support and decision making in the European Union. Ecosystem Services 1(1):31-39. https://doi.org/10.1016/i.ecoser.2012.06.004

Martín-López, B., I. Iniesta-Arandia, M. García-Llorente, I. Palomo, I. Casado-Arzuaga, D. G. Del Amo, E. GómezBaggethun, E. Oteros-Rozas, I. Palacios-Agundez, B. Willaarts, J. A. González, F. Santos-Martín, M. Onaindia, C. LópezSantiago, and C. Montes. 2012. Uncovering ecosystem service bundles through social preferences. Plos One 7(6):e38970. https:// doi.org/10.1371/journal.pone.0038970

Mensah, S., R. Veldtman, A. E. Assogbadjo, C. Ham, R. G. Kakaï, and T. Seifert. 2017. Ecosystem service importance and use vary with socio-environmental factors: a study from household-surveys in local communities of South Africa. Ecosystem Services 23:1-8. https://doi.org/10.1016/j.ecoser.2016.10.018

Milhano, A. P. F. R. 2008. Gestão dos recursos hídricos em Moçambique: Gaza - rio Limpopo. Lisbon University Institute, Lisbon, Portugal. [online] URL: https://repositorio.iscte-iul.pt/ handle/10071/1376

Myers, G. W. 1994. Competitive rights, competitive claims: land access in post-war Mozambique. Journal of Southern African Studies 20(4):603-632. https://doi.org/10.1080/03057079408708424

Nahuelhual, L., F. Benra Ochoa, F. Rojas, G. I. Díaz, and A. Carmona. 2016. Mapping social values of ecosystem services: What is behind the map? Ecology and Society 21(3):24. http://dx. doi.org/10.5751/ES-08676-210324

Paudyal, K., H. Baral, B. Burkhard, S. P. Bhandari, and R. J. Keenan. 2015. Participatory assessment and mapping of ecosystem services in a data-poor region: case study of community-managed forests in central Nepal. Ecosystem Services 13:81-92. https://doi.org/10.1016/j.ecoser.2015.01.007

Perez, C., E. M. Jones, P. Kristjanson, L. Cramer, P. K. Thornton, W. Förch, and C. Barahona. 2015. How resilient are farming households and communities to a changing climate in Africa? A gender-based perspective. Global Environmental Change 34:95-107. https://doi.org/10.1016/j.gloenvcha.2015.06.003

Peterson, G. D., Z. V. Harmáčková, M. Meacham, C. Queiroz, A. Jiménez-Aceituno, J. J. Kuiper, K. Malmborg, N. Sitas, and E. M. Bennett. 2018. Welcoming different perspectives in IPBES: "Nature's contributions to people" and "Ecosystem services". Ecology and Society 23(1):39. https://doi.org/10.5751/ES-10134-230139

Porsani, J., M. A. Caretta, and K. Lehtilä. 2019. Large-scale land acquisitions aggravate the feminization of poverty: findings from a case study in Mozambique. GeoJournal 84:215-236. https://doi. org/10.1007/s10708-017-9836-1

Porsani, J., and R. Lalander. 2018. Why does deliberative community consultation in large-scale land acquisitions fail? A critical analysis of Mozambican experiences. Iberoamerican Journal of Development Studies 7(2):164-193. https://doi. org/10.26754/ojs ried/ijds.274

Raimundo, I. M. 2008. The interaction of gender and migration: household relations in rural and urban Mozambique. Pages 191-208 in E. Uchendu, editor. Masculinities in contemporary Africa. Codesria, Dakar, Senegal.

Raudsepp-Hearne, C., G. D. Peterson, and E. M. Bennett. 2010. Ecosystem service bundles for analyzing tradeoffs in diverse landscapes. Proceedings of the National Academy of Sciences 107 (11):5242-5247. https://doi.org/10.1073/pnas.0907284107

Raymond, C. M., M. Giusti, and S. Barthel. 2018. An embodied perspective on the co-production of cultural ecosystem services: toward embodied ecosystems. Journal of Environmental Planning and Management 61(5-6):778-799. https://doi.org/10.1080/0964$\underline{0568.2017 .1312300}$

Raymond, C. M., G. G. Singh, K. Benessaiah, J. R. Bernhardt, J. Levine, H. Nelson, N. J. Turner, B. Norton, J. Tam, and K. M. A. Chan. 2013. Ecosystem services and beyond: using multiple metaphors to understand human-environment relationships. Bioscience 63(7):536-546. https://doi.org/10.1525/bio.2013.63.7.7 
Reed, J., J. van Vianen, S. Foli, J. Clendenning, K. Yang, M. MacDonald, G. Petrokofsky, C. Padoch, and T. Sunderland. 2017. Trees for life: the ecosystem service contribution of trees to food production and livelihoods in the tropics. Forest Policy and Economics 84:62-71. https://doi.org/10.1016/j.forpol.2017.01.012

Reilly, K., J. Adamowski, and K. John. 2018. Participatory mapping of ecosystem services to understand stakeholders' perceptions of the future of the Mactaquac Dam, Canada. Ecosystem Services 30(A):107-123. https://doi.org/10.1016/j. ecoser.2018.01.002

República de Moçambique. 2011. Plano estratégico para o desenvolvimento do setor agrário (PEDSA) 2011-2020. Ministério da Agricultura, Maputo, Mozambique. [online] URL: https://www.open.ac.uk/technology/mozambique/sites/www.open. ac.uk.technology.mozambique/files/pics/d130876.pdf

República de Moçambique. 2013. Plano nacional de investimento do setor agrário (PNISA) 2013-2017. Ministério da Agricultura, Maputo, Mozambique. [online] URL: http://extwprlegs1.fao.org/ docs/pdf/moz158423.pdf

República de Moçambique. 2017. Resultados definitivos: censo 2017. Instituto Nacional de Estatística, Maputo, Mozambique. [online] URL: http://www.ine.gov.mz/iv-rgph-2017/mocambique/ apresentacao-resultados-do-censo-2017-1/at download/file

Rönnbäck, P., B. Crona, and L. Ingwall. 2007. The return of ecosystem goods and services in replanted mangrove forests: perspectives from local communities in Kenya. Environmental Conservation 34(4):313-324. https://doi.org/10.1017/S0376892907004225

Scoones, I. 1998. Sustainable rural livelihoods: a framework for analysis. IDS Working Paper 72. Institute of Development Studies, Brighton, UK. [online] URL: https://www.ids.ac.uk/ publications/sustainable-rural-livelihoods-a-framework-for-analysis/

Scoones, I. 2009. Livelihoods perspectives and rural development. Journal of Peasant Studies 36(1):171-196. https://doi. org/10.1080/03066150902820503

Smithson, J. 2000. Using and analysing focus groups: limitations and possibilities. International Journal of Social Research Methodology 3(2):103-119. https://doi.org/10.1080/136455700405172

Solesbury, W. 2003. Sustainable livelihoods: a case study of the evolution of DFID policy. ODI Working Paper 217. Overseas Development Institute, London, UK. [online] URL: https://www. odi.org/publications/144-sustainable-livelihoods-case-study-evolutiondfid-policy

Tadesse, G., E. Zavaleta, C. Shennan, and M. FitzSimmons. 2014. Local ecosystem service use and assessment vary with socioecological conditions: a case of native coffee-forests in southwestern Ethiopia. Human Ecology 42:873-883. https://doi. org/10.1007/s10745-014-9704-2

Tauro, A., E. Gómez-Baggethun, E. García-Frapolli, E. Lazos Chavero, and P. Balvanera. 2018. Unraveling heterogeneity in the importance of ecosystem services: individual views of smallholders. Ecology and Society 23(4):11. https://doi. org/10.5751/ES-10457-230411
Wilkinson, S. 1998. Focus group methodology: a review. International Journal of Social Research Methodology 1 (3):181-203. https://doi.org/10.1080/13645579.1998.10846874

World Bank. 2018. Rural population (\% of total population). World Bank estimates based on the United Nations Population Division's world urbanization prospects: 2018 revision. World Bank, Washington, D.C., USA. [online] URL: https://data. worldbank.org/indicator/SP.RUR.TOTL.ZS?view=map

World Resources Institute, United Nations Development Programme, United Nations Environment Programme, and World Bank. 2005. World resources 2005: the wealth of the poor - managing ecosystems to fight poverty. World Resources Institute, Washington, D.C., USA. [online] URL: https://www. wri.org/publication/world-resources-2005-wealth-poor

Yang, Y. C. E., S. Passarelli, R. J. Lovell, and C. Ringler. 2018. Gendered perspectives of ecosystem services: a systematic review. Ecosystem Services 31(A):58-67. https://doi.org/10.1016/j. ecoser.2018.03.015

Yemiru, T., A. Roos, B. M. Campbell, and F. Bohlin. 2010. Forest incomes and poverty alleviation under participatory forest management in the Bale Highlands, Southern Ethiopia. International Forestry Review 12(1):66-77. https://doi.org/10.1505/ ifor.12.1.66

Yin, R. K. 2003. Case study research: design and methods. Sage, Thousand Oaks, California, USA.

Zhang, W., E. Kato, P. Bhandary, E. Nkonya, H. I. Ibrahim, M. Agbonlahor, H. Y. Ibrahim, and C. Cox. 2016. Awareness and perceptions of ecosystem services in relation to land use types: evidence from rural communities in Nigeria. Ecosystem Services 22(A):150-160. https://doi.org/10.1016/j.ecoser.2016.10.011 